\title{
AN ASSESSMENT OF THE LEGAL FRAMEWORK SAFEGUARDING ACADEMIC STAFF: A FACTOR IN THE DECLINING QUALITY OF HIGHER EDUCATION IN KENYA
}

\author{
Newton Ochieng Mitoko
}

Cite this article:

Newton Ochieng Mitoko (2021), An Assessment of the Legal Framework

Safeguarding Academic Staff: A Factor in the Declining Quality of Higher Education in Kenya. African Journal of Social Sciences and

Humanities Research 4(3), 4455. DOI: 10.52589/AJSSHRzoM6PVek.

\section{Manuscript History}

Received: 7 Feb 2020

Accepted: 18 March 2020

Published: 19 June 2021

Copyright $(0) 2020$ The Author(s). This is an Open Access article distributed under the terms of Creative Commons AttributionNonCommercial-NoDerivatives 4.0 International (CC BY-NC-ND 4.0 ), which permits anyone to share, use, reproduce and redistribute in any medium, provided the original author and source are credited.
ABSTRACT: A paper that seeks to investigate the legal framework safeguarding academic staff; whether or not, it has an impact on the declining quality of higher education in Kenya. Due to globalization and privatization of higher education, the field has been open to forces, which have seen institutions, become the centers of exploitation. Incidents in which university staff have threatened to strike or put down their tools have become the norm. Such situations have denied youth the right to access education. To remedy the foregoing problems, the parliament of Kenya enacted various legislation as part of reform efforts aimed at enhancing the efficiency, integrity and equity of Kenya's higher education system. Thus, purpose of the paper is to clearly analyze the legal framework and safeguards that relate to academic staff with the view to understand it's impact on Higher Education. Hence, quantitative research using a survey questionnaire to collect data from respondents was conducted. The end results of the study revealed that the current structured legal framework and safeguards for academic staff had a positive impact thus not a push factor in declining quality of higher education in Kenya.

KEYWORDS: Legal Framework, Higher Education, Academic Staf 


\section{INTRODUCTION}

\section{Background of the Paper}

In the modern fast growing competitive world, one need not mention the significance of education for the dignified life of an individual as well as that of a nation. Echoing this, the Education Commission in India (1987) stated that if change was ever to be achieved without violent revolution, there was one instrument that can be used education. Education is the only instrument that can reach all the people, sustain contribution to development as well as safeguard the interests of the stakeholders.

Due to the intimate connection between deterioration of standards and professionalism in higher education and conditions associated with economic decay. The U.N.E.S.C.O commission of education (1972) declared education a lifelong process and its purposes to establish a learning society. According to U.N.E.S.C.O's policy papers on "change and development of higher education" emphasized that the state and society must perceive higher education, not as a burden of the federal budgets but as a long term domestic investment.

Most african nations including Kenya have deceived themselves that the problem of higher education is one of lack of resources, donors, equipment and strategic plans. Although all these may lack, Thomas Kuhn argued forcefully in his 'scientific revolution' that no scientific enterprise or research can be conducted before identifying the paradigm that guides it. For instance, someone cannot start collecting data in Mathare or Kibera unless he is angry or happy about what goes on there; it would set a moral conviction that justifies the action.

For one to understand what is wrong with higher education in Kenya, they should focus more on the beliefs, values and legal aspects, instead of focusing on the political and financial aspects on which the concentration of reform in Kenya has been. Hence, this paper aims to further these investigations and find out more about the legislative framework safeguarding academic staff, its impact on the country's declining quality of higher education. Is there really a correlation between these two aspects? The paper seeks to substantiate if really the declining quality of education is attributable to the legal framework put in place to safeguard staff.

\section{Significance \& Objectives}

The paper aims to explore the correlation between the legal framework safeguarding academic staff and its impact on the declining performance of higehr education system in Kenya. Several scholars such as Max weber (2014), Thomas Kuhn (2016), Lord Keynes (2013), Pradhan (2015), all attest those sufficient strategies on worker welfare has positive impact on the whole education system and enhancement in legislation are the chief factors behind improvement of the system. These sources claim that government policy and legislation has been misconstrued to be the main factor behind the lessening quality of higher education in the region.

However, this is not the case because even after enactment of legislation, higher education quality still continues to decline at an alarming rate and lecturers are still striking. If indeed it is, the force behind the decline, the study will call upon the government and its key policymakers to provide policies and laws that will enable lecturers in university merge their personal interests with their students needs as well as the system. This will subsequently 
reduce the perils of Kenya's decline in higher education thus the paper will accomplish objectives such as analyze and explore the current legal aspects and status of academic staff in relation to the declining quality of higher education in kenya.

\section{Research Questions and Study Hypotheses}

This study is driven by the following research questions:

- Is there a relationship between legislation safeguarding academic staff and the declining quality of higher education in Kenya?

- What is the impact of this relationship?

- How best can this situation be improved?

Thus, the assumptions developed in this study, consist of a null and alternative hypothesis as follows:

H0: There is no significant relationship between legislation safeguarding academic staff and the declining quality of higher education in Kenya.

Ha: There is a significant relationship between legislation safeguarding academic staff and the declining quality of higher education in Kenya.

The null hypothesis (H0) claims that there is no significant relationship, this has been developed to posit that the current legal framework safeguarding academic staff is not a cause factor to declining quality of higher education. If the research analysis accepts this null hypothesis, it will be assumed that the higher education in Kenya is decreasing thanks to other outside factors such as lack of financial and infrastructural resources that have plagued the country.

\section{Statement of the Problem}

International Labour Organization I.L.O (1946) has passed various conventions in relation to welfare and safety of working class. These serve as international standards for legal framework setup up in member states. However, in Kenya, legislative measures protecting academic staff are taken as a cause factor in the declining quality of higher education. Raising the question as to functionality of the present legal framework or system.

\section{REVIEW OF AVAILABLE LITERATURE}

Literature Review is a core part of any paper as it embodies secondary data. According to Derntl (2014), it constitutes all forms of published academic material compiled by other researchers, journals, articles, census data etc.

In 1995, the Mungai Commission was set up to look into the Future Development of University Education in Kenya. It looked into all aspects of university education and made proposals to improve both the administrative and financial management of universities. 
Thereafter, another Commission of Inquiry into the Education System of Kenya known as the Koech Commission or Report was appointed under Gazette Notice numbers 2291 and 2292 of 14th May, 1998 to investigate issues related to the above and particularly mandated to recommend ways of enabling the education system facilitate national unity, mutual responsibility, accelerated industrial and technological development, life-long learning and adaptation etc in response to changing circumstance.

However, the reality on the ground is different, the following article flashed on www.standard digital news.com by Rawlings Otieno and Maureen was posted on the 14th May 2014 titled "Public Universities Staff Union issue strike threat". According to the union, they threatened to down their tools as long as the government and university management failed to honor the 3.9 billion pay deal. The article was published after a few months of a similar incidence in Nairobi, Kenya 2013 wherein university lecturers went on strike in spite of court orders.

The paper further goes ahead and picks from research paper published in journal of Educational and Social research VOL. (2) Sept 2011 by Hassan Danial Aslam titled "evaluation of teachers in Universities" whereby the researcher concluded that a key source for optimum performance was welfare and interests be protected and great results would be achieved. A remark supported by the confrence paper presented at the "mijadala on social policy, governance and development in Kenya" entitled "State of Higher Education in Kenya: problem6s and prospects" by Professor Michael Chege.Such review of past literature would help corroborate the findings of the primary data gathered; this corroboration of primary data against secondary data helps make the primary data more reliable and trustworthy (Cottrell, 2017).

\section{Structure and Limitations of the Study}

The rest of the paper shall be organized into further sections and the methodology used are quantitative survey questionnaires, observations and informal interactions which will feature questions touching on issues such as working conditions, educational attainment, legislation and status.

Another section will encompass the findings \& discussions. Wherein responses from the questionnaires shall be outlined and rigorously analyzed. It shall be triangulated with the secondary data to see if they resonate or have any commonalities.

The last section shall give a brief recap of the paper, review and verify its accomplishments, aims and objectives as initially set out. The researcher is aware of his limitations in the present study

\section{Methodology}

It is a comprehensive outline of the process implemented in mining, collecting, and analyzing raw data required. It starts off with an elucidation of the research philosophy, research approach, strategy, sampling technique and data collection methods. 


\section{Research Philosophy}

It was clearly put by Crossan (2003) when he explained, research philosophy as the conviction harbored by researchers regarding which method or style to use while collecting and analyzing data. The current paper undertakes the positivism philosophy, an ideal platform for us to collect and analyze numerical or categorical data as is intended in this study.

\section{Research Approach}

Research approach, as Sarma (2012) illuminates, consists of the means or routine a researcher follows to achieve the final data results to a study. This current paper takes on the deductive approach as it seeks to validate/nullify the paper hypothesis set out. Both positivism and deductive methodologies are geared towards collection of quantitative data in an objective manner and analysis/interpretation of this data in statistical means.

\section{Research Strategy}

A research strategy, as defined by Arghode (2012), comprises of the judgment that researchers reflect upon when deciding on the type of data to collect within a study. The current paper accommodates the quantitative research strategy because it uses quantitative data collection methods to gather data from the respondents; using a closed-ended survey questionnaire.

\section{Sampling Technique}

According Hammersley and Mairs (2004) define sampling as the method implemented by a researcher when sectioning off a distinct number of subjects from a larger population

Setia (2016) explained purposive sampling as the method used when sampling subjects who fulfill a certain purpose that a researcher has in mind. The paper is investigating the association between higher education versus legislative safeguards for academic staff. It purposively selected academic staff only to participate in the survey questionnaire. Hence, 50 respondents were readily available to fill out the questionnaires at the time the survey was administered.

\section{Ethical Considerations}

Ethical considerations comprise of the codes of conduct, decency, and integrity that a researcher is compelled to abide to when carrying out a research study. The paper similarly takes into great account the ethical considerations required when collecting information from human subjects. Rani and Sharma (2012) claims that it is very prudent to consider ethical measures when dealing with human participants in terms of ensuring that their safety and dignity is not put in jeopardy neither is their privacy compromised with. 


\section{DATA ACQUISITION \& ANALYSIS}

\section{Result Analysis}

The discussion of these results helps to reveal their meaning and relevance to this paper, demonstrating the challenges, connection or outcomes of legislative framework and the quality of higher education.

\section{Age}

Age is a common demographic question asked in surveys (Gjonça and Calderwood 2004, p. 16). The purpose of asking for respondents' ages is to determine how different age groups view similar situations. Below are the results for the respondents' ages (see Table 1 below).

Table 1: Age

\begin{tabular}{|l|r|c|}
\hline Age & Percent & Count \\
\hline 25-34 years & 38 & 16 \\
\hline 35-44 years & 20 & 20 \\
\hline 45-54 years & 10 & 10 \\
\hline 55-64 years & 32 & 4 \\
\hline$>65$ years & 0 & 0 \\
\hline
\end{tabular}

Most respondents are aged between 28 - 45 years; this is an advantage to the study because this particular age group is considered as the millennial group or as the Generation X (Kiersz 2015). People in this age group are considered as mature young adults thus, are expected to be idealistic, self-reliant, and responsible. Also, they are considered to have completed their basic education and have already joined the workforce, hence, are quite knowledgeable and insightful about a wide array of things (Kiersz 2015). In this paper, the age group is ideal as it is expected that they are aware about the decline in quality of higher education and whether legislative framework safeguarding academic staff negatively impacts eduaction.

\section{Education}

The purpose of asking for respondents' education level is to determine their aptitude level as well as their competence in answering the questions. Below are the results for the respondents' Education qualifications (see Table 2 below). 
Table 2: Education

\begin{tabular}{|l|c|c|}
\hline Answers & Percent & Count \\
\hline Postgraduate & $20.00 \%$ & 10 \\
\hline Professional Training Program & $50.00 \%$ & 25 \\
\hline University & $30.00 \%$ & 15 \\
\hline
\end{tabular}

Demographic statistics on education and age are somewhat correlated, such that, the older one is, the higher his/her educational level or attainment, hence the more discerning and quick-witted one is (Gjonça and Calderwood 2004, p. 17). In this paper, most respondents have gone as far as professional training program as well as university levels; this is an advantage because most seem to be well-educated and, thus, are well-informed.

\section{Further Studies/Education}

The reason behind asking whether the study respondents planned to go for further education or studies was to determine their perceptions towards the education system. Whereby if the respondents agree, this means they have faith in the educational system hence seeking for more knowledge or a better-quality education.

Table 3. Plans for Further Studies

\begin{tabular}{|l|l|l|}
\hline Answers & Percent & Count \\
\hline Yes & $23.00 \%$ & 23 \\
\hline No & $77.00 \%$ & 77 \\
\hline
\end{tabular}

\section{Employment/Profession}

Demographic questions about employment or profession enable the researcher to know if the study respondents have any stakeholder interest in educational issues. This data is especially important in surveys which mostly investigate performance. Below are the results on the respondents' employment status (see Table 4 below).

Table 4: Employment

\begin{tabular}{|l|c|c|}
\hline Answers & Percent & Count \\
\hline Full - Time & $80.00 \%$ & 35 \\
\hline Part - Time & $10.00 \%$ & 10 \\
\hline Other & $0.00 \%$ & 0 \\
\hline
\end{tabular}


Job Satisfaction

Table 5. Job Satisfaction

\begin{tabular}{|l|l|l|}
\hline Answers & Percent & Count \\
\hline Yes & $40.00 \%$ & 20 \\
\hline No & $60.00 \%$ & 25 \\
\hline & & \\
\hline
\end{tabular}

While going through the responses of the Academic staff, it reveals that $40 \%$ are satisfied with their job while $60 \%$ were not satisfied with their job. The percentage of the job satisfied employees/staff is on the lower side only because the workers mindset is that of fear and pressure due to high rate of unemployment.

\section{Presence of complications affecting Higher Education.}

This question tests if indeed the respondents have experienced any compliations, in so far, that affect higher education. Below are the results for this question (see Table 6 below).

Table 6: Presence of complications affecting Higher Education.

\begin{tabular}{|l|l|l|}
\hline Answers & Percent & Count \\
\hline Yes & $80.00 \%$ & 40 \\
\hline No & $20.00 \%$ & 10 \\
\hline
\end{tabular}

Apparently, majority respondents have experienced complications affecting education in Kenya while only 10 people said they have not experienced any complications.

\section{To what extent is the Reduction in Quality of Higher Education}

The question sought to find out the extent to which respondents have noticed reductions in the quality of higher education in Kenya. Table 7 below shows the results for this question.

Table 7: Extent of Reduction in Quality of Higher Education.

\begin{tabular}{|l|l|l|}
\hline Answers & Percent & Count \\
\hline To a great extent & $70.00 \%$ & 35 \\
\hline To a moderate extent & $20.00 \%$ & 10 \\
\hline To a minimal extent & $10.00 \%$ & 5 \\
\hline
\end{tabular}


The majority of the respondents noted the reduction in quality of higher education and about $20 \%$ of the respondents have only noticed a moderate reduction in quality of higher education.

Do you think the present legal system is working against academic staff in terms of their welfare?

Table 8

\begin{tabular}{|l|l|l|}
\hline Answers & Percent & Count \\
\hline Yes & $60.00 \%$ & 30 \\
\hline No & $38.00 \%$ & 16 \\
\hline Uncertain & $2.00 \%$ & 4 \\
\hline
\end{tabular}

$60 \%$ of respondents were of the opinion that the legal system was working against academic staff in terms of judgement issued in various litigation involving academic staff but only 16 respondents held that the legal system was working well with the educational system and $2 \%$ of the respondents were uncertain.

Would you say, that the legal system in relation to safeguarding academic staff is working against students and their education?

This question sought to find out whether the legal framework put in place to safeguard academic staff are working against students and their right to education.

Table 9: Extent of Hinderance

\begin{tabular}{|l|l|l|}
\hline Answers & Percent & Count \\
\hline Yes & $70.00 \%$ & 35 \\
\hline No & $10.00 \%$ & 5 \\
\hline Uncertain & $20.00 \%$ & 10 \\
\hline
\end{tabular}

From the data we can see that $70 \%$ of respondents were of the opinion that the legislative statutes for academic staff did indeed have hinderance on studemts and their rights in terms of delays and strikes by staff aggrieved staff who want reforms, legislation etc enacted for their benefit without due regard to student's welfare. However, only 5 respondents held that the legal system was working in tune with the educational system and thus experience no hinderance. 
Do you think someone should look into the present legal framework safeguarding academic staff's welfare? And make improvements?

This question sought to find out whether there was need to look or research into the present legal framework or legislation that safeguard academic staff welfare and whether or not improvements are needed.

Table 10: Recommendations for research and improvements

\begin{tabular}{|l|l|l|}
\hline Answers & Percent & Count \\
\hline Yes & $76.00 \%$ & 38 \\
\hline No & $16.00 \%$ & 8 \\
\hline Uncertain & $8.00 \%$ & 4 \\
\hline
\end{tabular}

From the data we can see that a large percentage i.e $76 \%$ of respondents were in agreement and thus pushed for more research and improvements to be conducted on the education industry.

It is alleged that the Govt. of Kenya uses the court to hinder academic staff to seek legal redressal? How true is this?

The question sought to uncover the truth to allegations that the Kenyan Government uses the court to hinder academic staff in seeking legal redress and whether such allegations are based on solid grounds.

Table 11:

\begin{tabular}{|l|l|l|}
\hline Answers & Percent & Count \\
\hline Yes & $66.00 \%$ & 28 \\
\hline No & $24.00 \%$ & 12 \\
\hline Uncertain & $20.00 \%$ & 10 \\
\hline
\end{tabular}

While going through the responses of the Academic staff, it reveals that $66 \%$ are certain of government interference while $24 \%$ held that there was no government interference nor intervention when it came to academic staff and their welfare. However, $20 \%$ of the respondents were uncertain thus the ratio may not be the true reflection of the issue.

\section{Extent you would change or improve higher education systems?}

The question sought to find out what the respondents disliked about the higher education system as while as the legal framework safeguarding academic staff, subsequently what they 
would change or improve. Respondents clarified more on the responses they gave. Stating that they did not like their experience so far. Overall, there were quite a lot of complaints forwarded by the respondents and what they would like improved.

\section{CONCLUSION}

\section{Impact of the relationship}

After analysis, various aspects such as poor working conditions, minimal salaries, allowances etc. are considered grounds for discontent among the academic staff and reason for their absence in the lecture halls. Such actions or behaviour have a negative impact on higher education as a result contribute to the declining rate of quality higher education in Kenya.

In addition, labor laws that are applicable to academic staff in public universities are not strictly implemented in Kenya. As a result, this has created the need to make amendments in legislations, whose provisions if amended would safeguard the welfare of the academic staff, thereafter positively impacting participation in higher education.

\section{Improvement of the Situation}

The need for major educational reforms is clear and the improvement of the present legal frame work comes into play, creating the need to amend the various legislative statutes in a way that is not only just, equitable but also protects the interests of the parties it purports to regulate or govern. In addition, such legislation should be amended to comply with international standards. As well as provide for regulations, procedures and provisions to tackle the issue of inadequate wages, salaries, pensions and other allowances. Finally, the government, in conjunction with the industry, needs to mobilize service providers to ameliorate their service provision quality.

\section{Limitations}

The paper so far, has been successful. However, there were a few limitations and difficulties encountered along the course. The main limitation encountered was the conflict between the choice of data collection method. It was really hard to choose between using either qualitative research strategy or a quantitative one.

Another limitation was that the paper gathered information from the lecturers only, thus the resulting opinions and information were limited to their views only. Hence, to get information that cuts across all sectors future studies may have to collect such data from the other education stakeholder respondents.

\section{Recommendations for Future Research}

The paper advocates for facilitation of qualitative data research for more in-depth evaluation and analysis of legislative framework and safeguards affecting academic staff \& quality standards of higher education not just in Kenya, but also in other jurisdictions as well. This will enable future researchers delve deeper into people's abstract thoughts, ideas, suggestions, and apprehension about the issue at hand. 


\section{REFERENCES}

A. Hassan Danial "Evaluation of Teachers in Universities" Journal of Educational and Social research VOL.(2) Sept 2012(4)

C. Michael. "State of Higher Education" presented at the Mijadala on Social Policy, Governance and Development in Kenya, Nairobi, 2012

Dr. B.N Mwaniki. International outlook on public universities. K.I.E Publications, Nairobi, Kenya. ( 2013)

Gjonça, E., and Calderwood, L., 2004. Socio-demographic characteristics. London, UK: Institute for Fiscal Studies.

J.R. Carter. Legal framework of Educational planning and Administration in East Africa. Nairobi, Kenya

Otieno. R., "Public Universities Staff Union issue strike threat". Internet: www.standarddigitalnews.com, May.14, 2014

P.R. Kinyuthia, Kenyan Labour and Inustrial laws. Kenya Law Publications, Nairobi, Kenya. (2008)

Prof.N. W. Makao. A view of Kenyan Labour statutes. Nairobi, Kenya. (2008).

Rani, R., \& Sharma, R. (2012). Ethical consideration in research. International Journal of Nursing Education, 4(1), 45-48.

S.N Misea, Labour \& industrial laws. Central Law Publications, Nairobi, Kenya. (2006)

Sarma, R. (2012). Research: In a methodological frame. Researchers World: Journal of Arts, Science 7 Commerce, 3(1), 97-106.

Setia, M. (2016). Methodology series module 5: Sampling strategies. Indian Journal of Dermatology, 61(5), 505-509. 